\title{
Association of eating patterns and abdominal adiposity in Brazilian
}

\section{Associação de padrões alimentares e adiposidade abdominal em adultos brasileiros}

\section{A B S T R A C T}

\section{Objective}

To examine the relationship between dietary patterns and abdominal adiposity among adults living in the urban area of Viçosa, Minas Gerais, Brazil.

\section{Methods}

A population-based, cross-sectional study of 959 adults of both sexes. Information on sociodemographic characteristics and dietary intake was collected through questionnaires. Abdominal adiposity was evaluated using waist circumference and the anthropometric indices waist-to-hip ratio and waist-to-height ratio. Food patterns were identified by factor analysis. Poisson regression was used for multivariate analysis.

\section{Results}

Abdominal adiposity was identified by waist circumference in $59.06 \%(95 \% \mathrm{Cl}=52.77-65.08)$ of the sample, by waist-to-hip ratio in $54.65 \%(95 \% \mathrm{Cl}=47.92-61.21)$, and by waist-to-height ratio in $9 \%(95 \% \mathrm{Cl}=54.61-69.03)$. Two dietary patterns, named as traditional Brazilian and bar, were identified in the sample, but only the latter was statistically associated with abdominal adiposity determined by the three parameters.

\section{Conclusion}

The study identified two eating patterns in the population, a healthy and an unhealthy pattern, the latter being associated with greater odds of abdominal adiposity. Thus, it is important to take measures to reverse this trend.

Keywords: Factor analysis. Feeding behavior. Obesity abdominal.

\footnotetext{
1 Universidade Federal do Oeste da Bahia, Centro das Ciências Biológicas e da Saúde, Núcleo de Nutrição. R. Prof. José Seabra de Lemos, 316, Recanto dos Pássaros, 47808-02, Barreiras, BA, Brasil. Correspondência para/Correspondence to: DCG SILVA. E-mail: <daniellenut@hotmail.com>.

2 Universidade Federal de Viçosa, Centro de Ciências Biológicas, Departamento de Nutrição e Saúde. Viçosa, MG, Brasil.
} 


\section{R E S U M O}

\section{Objetivo}

Explorar a relação entre padrões alimentares e a adiposidade abdominal entre adultos residentes na área urbana do município de Viçosa, Minas Gerais.

\section{Métodos}

Estudo transversal, de base populacional, realizado com 959 indivíduos adultos e de ambos os sexos. Foram coletadas informações sobre as características sociodemográficas e de consumo alimentar por meio de questionários. Para avaliação da adiposidade abdominal, avaliou-se o perímetro da cintura e os índices antropométricos relação cintura/quadril e relação cintura/estatura. Os padrões alimentares foram identificados por análise fatorial. Para análise multivariada, foi utilizada regressão de Poisson.

\section{Resultados}

A adiposidade abdominal identificada pela perímetro da cintura foi de 59,06\% (IC95\%=52,77-65,08), pela relação cintura/quadril foi de 54,65\% (IC95\%=47,92-61,21) e pela relação cintura/estatura de 62,09\% (IC95\%=54,61-69,03). Foram identificados dois padrões alimentares, nomeados de padrão "tradicional" e "bar", sendo que somente o último padrão foi estatisticamente associado à adiposidade abdominal determinada pelos três parâmetros.

\section{Conclusão}

A população do estudo apresentou dois padrões alimentares, um considerado saudável e outro não saudável, o qual foi associado à maior chance de adiposidade abdominal. Sendo assim, medidas que revertam tais situações são importantes de serem adotadas.

Palavras-chave: Análise fatorial. Comportamento alimentar. Adiposidade abdominal.

\section{NTRODUCTION}

Dietary patterns can be effective indicators of the impact of diet on health outcomes, since they display the combined effects of diet intake [1]. The identification of dietary patterns emerged as an alternative method for studying the relationship between diet and chronic non-communicable diseases. Studies based on nutritional epidemiology have traditionally focused on the relationship between disease and specific nutrients and/or foods, however, the analysis of patterns focuses on the study of the combinations of nutrients and/or foods that the population usually consumes $[2,3]$. Thus, it has the advantage of allowing a more complete view of the diet, and how it affects health and disease [4]. Currently, food patterns have been identified by using statistical techniques that reduce and/or aggregate components such as the exploratory factor analysis followed by principal component analysis.

Diet may influence the development of abdominal adiposity. Studies have shown the association between unhealthy eating patterns and both general and abdominal obesity and identified mainly the consumption of red meat, whole dairy, processed foods, refined grains, high amounts of trans fat, and simple carbohydrates as predictors of such metabolic disorders [5-7]. However, consumption of healthy foods such as fruit, vegetables, low-fat meats, high-fiber diets, and low-glycemic index foods has been linked to the protective effect against general and central obesity $[7,8]$.

Data from the National Health and Nutrition Examination Survey show that the prevalence of abdominal obesity in the United States has increased significantly, reaching $54.2 \%$ of the total adult population in 2012 [9]. In Brazil, there are still few population studies on the distribution of adipose tissue in the abdominal region and its relation with dietary pattern [10], as well as on trends of abdominal obesity in populations. However, studies have shown the high prevalence of this condition [11,12].

The objective of this study was to examine the relationship between dietary patterns and 
abdominal adiposity among adults living in the urban area of Viçosa, Minas Gerais, Brazil.

\section{METHODS}

\section{Study population}

A cross-sectional study carried out between 2012 and 2014 by the Health and Food Studies Group of Viçosa, with adult individuals aged 20 to 59 years, both sexes, through a population-based household survey in the urban area of the municipality of Viçosa. According to the 2010 demographic census, Viçosa has 72,220 inhabitants, with 93.00\% residing in the urban area. Females predominate, constituting $51.50 \%$ of the population, and adults correspond to $60.13 \%$.

The sample size was calculated by the formula for estimating prevalence from the total number of individuals aged between 20 and 59 years residing in the urban area of Viçosa $(43,431)$ [13], estimated prevalence of $50 \%$ (the study is part of a thematic research project with other outcomes), 95\% Confidence Interval $(95 \% \mathrm{Cl})$, sampling error of 4.5 percentage points, and estimated design effect of 1.5. There was an increase of $10 \%$ for losses and refusals and $10 \%$ for control of confounding factors. The sample size (n) of 844 participants was estimated by Epi Info (Atlanta, Georgia, United States) 3.5.2 [14]. Pregnant women, postpartum women, individuals who were bedridden or unable to be measured, individuals with cognitive/intellectual difficulties or who had difficulty answering the questionnaire were not included in the study.

The research was approved by the Research Ethics Committee of the Universidade Federal de Viçosa, approval $\mathrm{n}^{\circ} 008 / 12$. All participants have signed the Free and Informed Consent Form.

Data collection consisted of two stages: home visits with the application of a structured questionnaire with questions on sociodemographic and behavioral characteristics of the research participants, anthropometric evaluation, and data on food consumption. The questionnaires were applied by a team of interviewers and supervisors previously trained. The field work and all instruments used for data collection were previously calibrated and tested in a pilot study [15].

The Instituto Brasileiro de Geografia e Estatística (IBGE) divides the municipality into 99 census tracts, among which 30 sectors were randomly selected to be included in the study. Within each sector, a new random draw was held to establish a starting point to choose the houses to be visited and include all eligible participants from each household.

The sociodemographic variables used in the study were: age in completed years and categorized in ten-year periods $(20-29,30$ $39,40-49$, and 50-59 years), educational level (as defined as $0-3,4-7$, and $\geq 8$ years of schooling); socioeconomic level, as determined by the Associação Brasileira de Empresas de Pesquisa [16] and classified as A and B (high), C (intermediate), and D and $\mathrm{E}$ (low). Marital status was categorized as married/in stable union (with partner) and not married (without partner). The behavioral variables used were: smoking, as categorized as non-smokers, current smokers, and ex-smokers [17]; abusive consumption of alcoholic beverages, estimated by the intake of at least five drinks at one sitting, over the past thirty days, for men, and at least four drinks for women, considering the standard dose as the intake of a half bottle or a can of beer, a glass of wine or a shot of distilled drink [18]. Screen time was evaluated by the sum of the time spent with television or computer programs on weekdays and weekends, during free time. The cut-off point was the sum of time greater than or equal to five hours a day, in front of the television or using the computer, to be considered excessive [19].

Waist circumference, Waist/Hip Ratio (WHR), and Waist-to-Height Ratio (WHtR) 
were evaluated for the determination of excess abdominal adiposity. Waist circumference was measured at the midpoint between the iliac crest and the last rib, and hip circumference was measured at the level of greatest protuberance of the buttocks, both using a 2-m inelastic measuring tape (Sanny ${ }^{\circledR}$, São Bernardo do Campo, São Paulo, Brazil). Height was measured with a $2.5 \mathrm{~m}$, wall-mounted stadiometer (Welmy, Santa Barbara D'Oeste, São Paulo, Brazil) to the nearest $0.1 \mathrm{~cm}$. The cut-off points used to determine excess abdominal adiposity based on the waist circumference evaluation were according to WHO [20], considering that men with waist circumference $\geq 94 \mathrm{~cm}$ and women with waist circumference $\geq 80 \mathrm{~cm}$ had central obesity. WHR was determined by the following equation: [WHR=waist circumference/ hip circumference $(\mathrm{cm})$ ], and the cut-off points were men with a ratio $\geq 1$ and women $\geq 0.85$ had central obesity. For WHtR, males and females with values $\geq 0.5$ were classified as with excess abdominal adiposity [21].

The information on the habitual food consumption of the participants was obtained from a Food Frequency Questionnaire (FFQ) developed in the pilot project by the application of 83 24-hour dietary recalls [15]. The quantitative FFQ included questions regarding the habitual consumption of 95 food items, allocated in 26 food groups, during one year, from consumption frequencies ranging from 0 to 12 times and time units as day, week, month, and year (Chart 1). Food portions were defined as small, medium, large and extra-large, corresponding to the percentiles $25,50,75$, and 95 , respectively, of the intake of each food item in grams. The mediumsize portion was defined as the reference and presented to the participants as household measures and in in grams. Of the 95 items that composed the FFQ, two were excluded (soy milk and flaxchia) because they had consumption frequency of less than 15\% [22].

Quality control was carried out by the random application of questions in the questionnaire to $10 \%$ of the sample via telephone and the double typing of the questionnaire by previously trained typists.

The dietary patterns were obtained a posteriori, applying the factor analysis methodology to the FFQ answers. The Kaiser-Mayer-Olkin coefficient (KMO) and the Bartlett's test of sphericity were performed before the factor analysis to verify the applicability of the statistical analysis.

Subsequently, factors were excluded by using principal components analysis and orthogonal varimax rotation. The factors with eingenvalues $>2$ were retained, as defined by the scree plot of the variances against the number of components. The exploratory factor structure was obtained from the indicators with factor loads higher than 0.25 and the standards were labeled according to the nutritional composition of the foods. The factor scores were divided into quartiles and categorized as low adherence (1st quartile), moderate adherence (2nd and 3rd quartile), and high adherence (upper quartile).

The association between dietary patterns and abdominal adiposity was evaluated using the prevalence ratios estimated by the Poisson Regression model. The main independent variable was the score of the quartile patterns, and the models were adjusted for the variables in blocks. The first model was adjusted for socio-demographic variables: gender, age, socioeconomic status; and marital status; and the second model was adjusted for behavioral variables: smoking habit, use of alcoholic beverages, and screen time. Statistical significance was $5 \%(p<0.05)$.

The analysis was weighted by sex, age, and schooling, according to IBGE population data for the municipality in 2010 [12], considering the effect of the sampling design, using the Stata commands "svy". The analyses were performed using the Stata statistical software, version 13.1.

\section{RES U L T S}

Data from 959 adults were analyzed. Relative to sociodemographic characteristics, 
the sample was predominantly composed of women, $50.20 \%(95 \% \mathrm{Cl}=46.13-54.25)$; in the age group 20-29 years, 30.29\% (IC95\%=21.9740.15); followed by individuals aged 30-39 years, $25.23 \%(95 \% \mathrm{Cl}=21.04-29.94) ; 8$ or more years of schooling, $72.76 \% \quad(95 \% \mathrm{Cl}=61.88-81.46)$; intermediate socioeconomic level, $64.7 \%$ (95\% Cl=60.72-71.18); and not married (without partner), 52.31\% (95\%Cl=42.54-61.90). Regarding the behavioral characteristics, $65.45 \%$ of the sample were nonsmokers (95\% Cl=59.31-71.11); $61.05 \%$ reported no abusive consumption of alcoholic beverages (IC95\%=56.36-65.54); and $89.80 \%$ reported no excessive television viewing and computer use (95\% Cl=87.63-91.63). Excess abdominal adiposity identified by the waist circunference measurement was $59.06 \%(95 \% \mathrm{Cl}=52.77-65.08), 54.65 \%$ $(\mathrm{Cl} 195 \%=47.92-61.2$ by $\mathrm{WHR}$, and $62.09 \%$ (95\% Cl=54.61-69.03) by $\mathrm{WHtR}$.

The tests to evaluate the correlations between the food items described in Table 1 and sampling adequacy in the factor analysis to identify the behavioral patterns were satisfactory for the exploratory factor analysis $(\mathrm{KMO}=0.75$ and Bartlett's sphericity <0.001). After the orthogonal varimax rotation, eight components were found: two with eigenvalues

Chart 1. Food groups of the Food Frequency Questionnaire used in the factor analysis. Viçosa (MG), Brazil, 2012-2014.

\begin{tabular}{|c|c|}
\hline Food groups & Food items from the Food Frequency Questionnaire \\
\hline Olive and green corn & Olive and green corn \\
\hline Popcorn & Popcorn \\
\hline Sandwiches & Hot joint, Hamburger \\
\hline Red meat & Beef or pork, meatballs, hamburger steak \\
\hline White meat & Chicken and fish \\
\hline Eggs & Eggs (cooked, scrambled, fried) \\
\hline Bean & Bean \\
\hline Tropeiro beans and feijoada & Tropeiro beans and feijoada \\
\hline Vegetable/olive oil & Vegetable/Olive oil \\
\hline Margarine, butter, mayonnaise & Margarine, butter, mayonnaise \\
\hline Fried potato and fried cassava & Fried potato and fried cassava \\
\hline Oats, granola, cereal bar & Oats, granola, cereal bar \\
\hline Milk & Whole milk, semi-skimmed milk, skimmed milk \\
\hline Spices & Garlic paste, garlic, onion, seasoning, knoor broth, ketchup and mustard \\
\hline Fruit & $\begin{array}{l}\text { Pineapple, melon, watermelon, orange, gourd, guava, peach, mango, banana, apple, pear, } \\
\text { papaya, grape, strawberry, plum, fruit salad, and fruit juices in general. }\end{array}$ \\
\hline Cheeses and yoghurts & Cheeses and yoghurts \\
\hline Sausages & Mortadella, ham, salami, sausage and sausage \\
\hline Vegetables & $\begin{array}{l}\text { Lettuce, allspice, cabbage, watercress, arugula, zucchini, chuchu, okra, broccoli, cauliflower, } \\
\text { cabbage, beetroot, carrot, pumpkin, tomato, vinaigrette }\end{array}$ \\
\hline Alcoholic beverages & Beer, wine, liquor, drip, whiskey, cognac \\
\hline Coffees and teas & Coffee and teas \\
\hline Soft drinks and artificial juices & Soft drinks and artificial juices \\
\hline Pastas & Pasta (pasta, noodles, lasagna), pizza \\
\hline Cereals & Soups, white rice, angu, farofa, sweet or sweet potatoes, cooked cassava \\
\hline Chips & Fried and baked \\
\hline Bread and biscuits & Breads, cheese bread, toast, plain cake, and biscuits \\
\hline Sweets and chocolates & Sweets in general and chocolates \\
\hline
\end{tabular}


above 2.0 , explaining $15.83 \%$ of the component variance, representing two dietary patterns. Those indicators with loads greater than 0.25 (indicated in bold) were considered as valid to remain in each component.

The two patterns identified were classified as: the traditional pattern, which was positively loaded for eggs, vegetable oils, oat, granola, cereal bar, milks, fruit, cheeses, yogurts, vegetables, breads, and biscuits, which accounted for $8.07 \%$ of the variance of food consumption; and the bar pattern, consisting of sandwiches, red meat, "tropeiro" beans (made with beans, sausage, bacon, collard greens, eggs, and cassava flour) and "feijoada" (stew made with black beans and pork meat), fried potatoes, fried cassava, sausages, alcoholic beverages, pasta, and salty snacks, which explained $7.77 \%$ of the variance of food consumption.

Table 2 shows the association between dietary patterns and abdominal adiposity. We found that the greater the adherence to the traditional pattern, the greater the protection against excess abdominal adiposity, however,

Table 1. Dietary patterns and factor load of food patterns derived from principal component analysis.

\begin{tabular}{|c|c|c|c|}
\hline \multirow{2}{*}{ Food Group } & \multicolumn{2}{|c|}{ Dietary Pattern } & \multirow{2}{*}{ Communality } \\
\hline & Tradicional & Bar & \\
\hline Olive and green corn & 0.01 & -0.04 & 0.5959 \\
\hline Popcorn & 0.12 & 0.01 & 0.4482 \\
\hline Sandwiches & 0.05 & 0.45 & 0.4481 \\
\hline Red meat & 0.20 & 0.54 & 0.4706 \\
\hline White meat & 0.01 & 0.06 & 0.6743 \\
\hline Eggs & 0.25 & 0.21 & 0.5254 \\
\hline Bean & 0.05 & 0.05 & 0.7019 \\
\hline Tropeiro beans and feijoada & 0.09 & 0.39 & 0.2829 \\
\hline Vegetable/olive oil & 0.32 & 0.20 & 0.5396 \\
\hline Margarine, butter, mayonnaise & -0.01 & 0.10 & 0.5816 \\
\hline Fried potato and fried cassava & -0.08 & 0.44 & 0.3244 \\
\hline Oat, granola, cereal bar & 0.52 & -0.14 & 0.4413 \\
\hline Milk & 0.42 & 0.01 & 0.4581 \\
\hline Spices & 0.07 & 0.03 & 0.5405 \\
\hline Fruits & 0.61 & -0.07 & 0.4499 \\
\hline Cheeses and yoghurts & 0.67 & 0.16 & 0.5456 \\
\hline Sausages & 0.02 & 0.52 & 0.5386 \\
\hline Vegetables & 0.55 & -0.06 & 0.5224 \\
\hline Alcoholic beverages & -0.12 & 0.61 & 0.4401 \\
\hline Coffee and teas & 0.01 & -0.14 & 0.5695 \\
\hline Soft drinks and artificial juices & -0.10 & 0.01 & 0.5638 \\
\hline Pastas & 0.04 & 0.33 & 0.6040 \\
\hline Cereals & -0.06 & 0.02 & 0.6271 \\
\hline Chips & 0.09 & 0.47 & 0.3012 \\
\hline Bread and biscuits & 0.42 & 0.15 & 0.5440 \\
\hline Sweets and chocolates & 0.23 & 0.12 & 0.5463 \\
\hline Eigenvalues & 2.09 & 2.01 & \\
\hline$\%$ variance explained & 8.07 & 7.77 & \\
\hline$\%$ cumulative explained variance & 8.07 & 15.83 & \\
\hline
\end{tabular}

Note: Indicators with factor loads greater than or equal to 0.25 are in bold. 


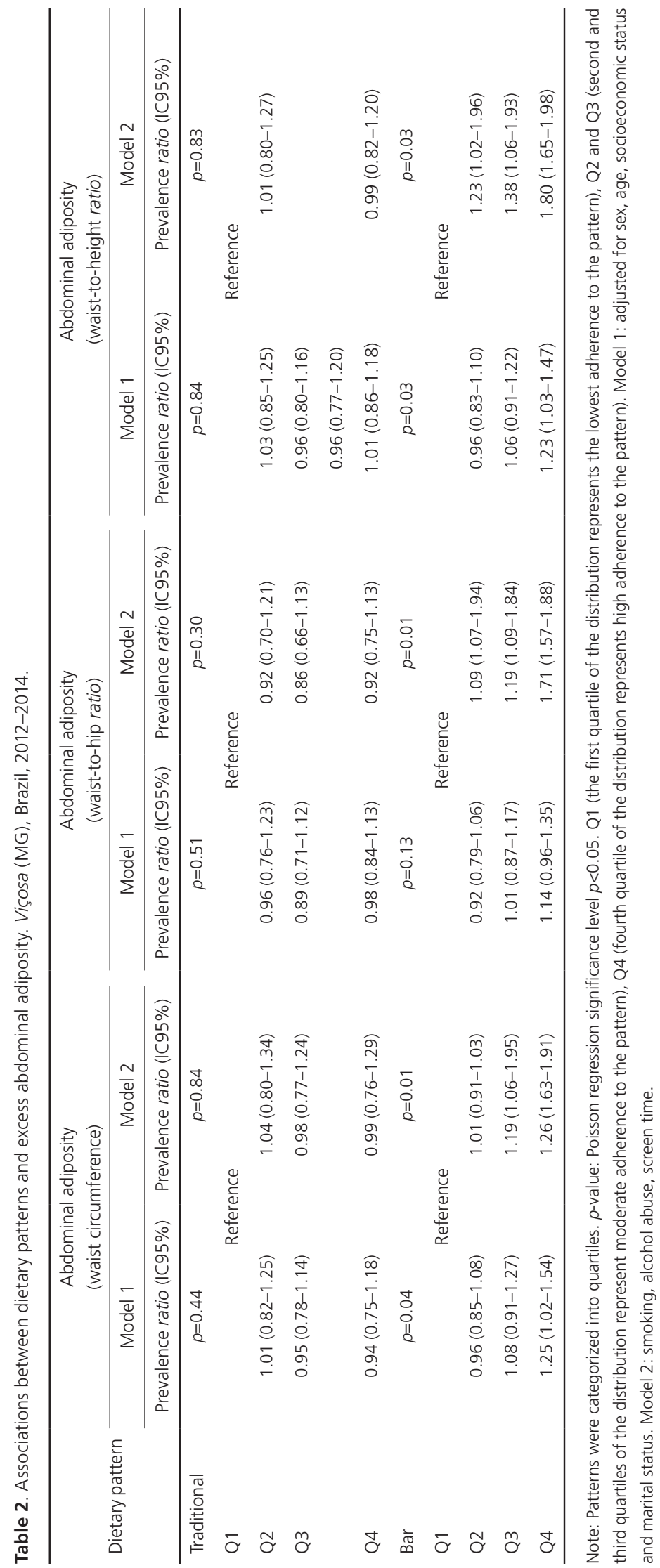


the associations were not significant for the two models of adjustment.

The bar pattern, in the fourth quartile (high adherence), is associated with abdominal adiposity, as determined by the waist circumference (prevalence Ratio $[\mathrm{PR}]=1.254,95 \% \mathrm{Cl}=1.021-1.540)$ and $\mathrm{WHR}$ ratio ( $\mathrm{PR}=1.228 ; 95 \% \mathrm{Cl}=1.026-1.471)$, after adjustment for sociodemographic variables. This pattern, in the fourth quartile (high adherence), after adjustments for behavioral variables, was shown to be associated with all parameters of abdominal adiposity evaluated.

\section{DISCUSSION}

In the present study, two dietary patterns (traditional and bar) were identified among Brazilian adults. The traditional pattern was not found associated with the lower odds of abdominal adiposity, and the bar pattern was associated with abdominal adiposity in adults.

The traditional pattern identified in this study was characterized by the consumption of traditional Brazilian foods, such as eggs, vegetable/olive oil, cereals, milks, fruit, cheeses, yogurts, vegetables, breads, and biscuits. Although some epidemiological investigations have shown a significant increase in the sale of ultraprocessed products, which between 2000 and 2013 increased by $43.7 \%$ worldwide $[23,24]$, the traditional pattern was the most representative of our population. It includes food items similar to those studies conducted by Gutiérrez-Pliego et al. [3] and Vilela et al. [6], from Spain and Brazil, respectively, who named them as prudent, and McEvoy et al. [25], who investigated diet patterns in several European countries and named them as healthy.

The bar pattern was characterized by grouping the food items such as sandwiches, red meats, "feijoada", potato chips, alcoholic beverages, sausages, and pasta. It is similar to patterns found by Gutiérrez-Pliego et al. [3], named as "high protein and animal fat", in a study with the Spanish population, and by Rodrigues et al. [26] and Ferreira et al. [27], in studies with the Brazilian population, who named the patterns as "western and snacks" and "weekend meals", respectively.

The difference in dietary patterns denominations was discussed in the systematic review carried out by Borges et al. [28], who found that the patterns named "western", "unhealthy" or "processed" refer to the consumption of food such as soft drinks, processed food, and sweets which are associated with a poorer quality of life; whereas the patterns named "healthy", "traditional", "Mediterranean", and "prudent" are characterized by foods such as cereals, fruit and vegetables, and are associated with a better quality of life. In addition, the authors reported that the category of qualitative labels (traditional, healthy, western) was used in $44 \%$ of the national and international studies reviewed $(n=84)$.

Epidemiological studies have demonstrated positive relationships between appropriate eating patterns and the lower odds of abdominal adiposity $[29,30]$. However, after analyses adjusted for both sociodemographic and behavioral variables, we found that the dietary patterns named as traditional was not associated with the lower odds of abdominal fat, although lower values were found for the prevalence rates of abdominal adiposity, according to the increase in the quartiles of the dietary pattern. In the same manner, a national study conducted in Italy found no significant association between the lower odds of abdominal adiposity and the dietary standard considered healthy, named as Mediterranean Diet [31].

Vilela et al. [6] found an unexpected positive association between the traditional dietary patterns and abdominal adiposity. However, the authors mention that this dietary patterns named as traditional included typical foods of the region, with high energy density, which may 
have contributed to the greater accumulation of abdominal fat.

Olinto et al. [32], in a cohort study with adults carried out in Pelotas, Rio Grande do Sul, Brazil, found significant inverse associations between the scores of the upper quartiles of the Brazilian common dietary pattern considered as healthy and abdominal adiposity represented by the waist circumference.

The bar dietary pattern was positively associated with abdominal obesity, which was determined by the increased parameters waist circumference, waist-to-hip ratio, and WHR ratio. Arruda et al. [33] studied the association of dietary patterns with both excess weight and abdominal obesity in young adults in São Paulo. The authors also found an association of the unhealthy dietary pattern, named as bar, with excess weight and abdominal obesity identified by the increase in the waist-to-height ratio, and the highest adherence to the dietary patterns was associated with the highest prevalence of abdominal obesity. In this same study, they identified a dietary pattern named as energy dense that was not associated with the greater odds of abdominal adiposity, which may be explained by reverse causality. The dietary pattern named as modern diet, characterized by a high consumption of processed foods and fast foods, was also associated with general obesity and abdominal obesity in the Chinese population [34].

Excess abdominal adiposity can be triggered by the various aspects of the modern lifestyle such as improper nutrition, physical inactivity, and stress. Unhealthy eating habits, consisting of diets with energy density, high contents of saturated and trans lipids influence the accumulation of abdominal adiposity. Physical inactivity and stress play a role in the distribution of adipose tissue in the body, since the increase in visceral fat is associated with stress through the release of cortisol and catecholamines. Cytokines from visceral adipose tissue lead to chronic subclinical inflammation and insulin resistance, which destabilize glycoprotein metabolism [35].

This is a population-based, cross-sectional study conducted in the city of Viçosa that sought to identify and associate dietary patterns with abdominal adiposity through the identification of patterns $[25,27,36]$. However, some limitations of this study must be considered as, for instance, errors inherent to dietary inquiries, such as difficulties in estimating food portions and recalling food consumption. Moreover, the subjectivity of the factor analysis, which requires decision-making by the researcher to define from grouping of foods to naming the patterns, deserves special attention.

\section{CONCLUSION}

Due to the high prevalence of abdominal adiposity, it is important that the population studied follow the recommendations for reducing the consumption of high calorie foods such as fast foods and alcoholic beverages, in order to benefit from a healthier dietary pattern and thus reduce the risk of general obesity, abdominal obesity, and chronic non-communicable diseases.

\section{CONTRIBUTORS}

All authors contributed in all phases of the research article.

\section{REFERENCES}

1. Xu X, Hall J, Byles J, Shi Z. Dietary pattern is associated with obesity in older people in China: Data from China Health and Nutrition Survey (CHNS). Nutrients. 2015;7(9):8170-88.

2. Aldana MF. Aplicaciones, dificultades y perspectivas del uso de patrones dietarios para entender la relación entre dieta y salud. Salud Pública México. 2007:49:106.

3. Gutiérrez-Pliego LE, Camarillo-Romero ES, Montenegro-Morales LP, Garduño-García JJ. Dietary patterns associated with body mass index (BMI) and lifestyle in Mexican adolescentes. BMC Public Health. 2016;16(1):850. 
4. Kant AK. Dietary patterns and health outcomes. J Acad Nutr Diet. 2004;104(4):615-35.

5. Denova-Gutiérrez E, Castañón S, Talavera JO, Flores M, Macías N, Rodríguez-Ramírez S, et al. Dietary patterns are associated with different indexes of adiposity and obesity in an urban. J Nutr. 2011;141(5):921-7.

6. Vilela AAF, Sichieri $R$, Pereira RA, Cunha DB, Rodrigues PRM, Gonçalves-Silva RMV, et al. Dietary patterns associated with anthropometric indicators of abdominal fat in adults. Cad Saúde Pública. 2014;30(3):502-10.

7. Perozzo G, Olinto MTA, Dias-da-Costa JS, Henn RL, Sarriera J, Pattussi MP. Associação dos padrões alimentares com obesidade geral e abdominal em mulheres residentes no Sul do Brasil. Cad Saúde Pública. 2008;24(10):2427-39.

8. Moreira PL, Corrente JE, Villas Boas PJF, Ferreira ALA. Dietary patterns are associated with general and central obesity in elderly living in a Brazilian city. Rev Assoc Med Bras. 2014;60(5):457-64.

9. Friedman DS, Ford ES. Are the recent secular increases in the waist circumference of adults independent of changes in BMI? Am J Clin Nutr. 2015;101(3):425-31.

10. Oliveira LC, West LEM, Araújo EA, Brito JS, Nascimento SCL. Prevalência de adiposidade abdominal em adultos de São Francisco do Conde, Bahia, Brasil, 2010. Epidemiol Serv Saúde. 2015;24(1):135-44.

11. Olinto MTA, Nácul LC, Dias-da-Costa JS, Gigante DP, Menezes AMB, Macedo S. Níveis de intervenção para obesidade abdominal: prevalência e fatores associados. Cad Saúde Pública. 2006;22(6):120715.

12. Costa MAP, Vasconcelos AGG, Fonseca MJM. Prevalência de obesidade, excesso de peso e obesidade abdominal e associação com prática de atividade física em uma universidade federal. Rev Bras Epidemiol. 2014;17(2):421-36.

13. Instituto Brasileiro de Geografia e Estatística. Censo demográfico 2010. Rio de Janeiro: IBGE; 2010.

14. Dean AG, Dean JA, Colombier D, Brendel KA, Smith DC, Burton AH, et al. Epi Info, version 6: A word processing, database, and statistics program for epidemiology on microcomputers. Atlanta (GA): Centers for Disease Control and Prevention; 1994.

15. Segheto W, Silva DCG, Coelho FA, Reis VG, Morais SHO, Marins JCB Body adiposity index and associated factors in adults: Method and logistics of a population-based study. Nutr Hosp. 2015;32:101-9.
16. Associação Brasileira de Empresas de Pesquisa. Critério de classificação econômica Brasil, 2011 [acesso 2015 fev 25]. Disponível em: www.abep. com.br

17. Menezes AMB, Victora CG, Perez-Padilla R. The Platino project: Methodology of a multicenter prevalence survey of chronic obstructive pulmonary disease in major Latin American cities. BMC Med Res Methodol. 2004;4(15):1-17.

18. Furlan-Viebig R, Pastor-Valero M. Development of a food frequency questionnaire to study diet and non-communicable diseases in adult population. Rev Saúde Pública. 2014;38(4):581-4.

19. Vasconcellos MB, Anjos LA, Vasconcellos MTL. Estado nutricional e tempo de tela de escolares do ensino fundamental do município de Niterói, RJ. Cad Saúde Pública. 2013;29(4):713-22

20. International Diabetes Federation. The IDF consensus worldwide definition of the metabolic syndrome. Brussels: International Diabetes Federation; 2005.

21. Ashwell M, Hsieh SD. Six reasons why the waistto-height ratio is a rapid and effective global indicator for health risks of obesity and how its use could simplify the international public health message on obesity. Int J Food Sci Nutr. 2005;56(5):303-7.

22. Hoffmann M, Mendes KG, Canuto R, Garcez $A S$, Theodoro $H$, Rodrigues $A D$, et al. Padrões alimentares de mulheres no climatério em atendimento ambulatorial no Sul do Brasil. Ciênc Saúde Coletiva. 2015;20(5):1565-74.

23. Pan American Health Organization. Ultra-processed food and drink products in Latin America: Trends, impact on obesity, policy implications. Washington (DC): PAHO; 2015.

24. Monteiro CA, Moubarac JC, Cannon G, Ng SW, Popkin B. Ultra-processed products are becoming dominant in the global food system. Obes Res. 2013;14(Suppl. 2):21-28.

25. McEvoy CT, Cardwell CR, Chakravarthy U, Hogg RE, McKinley MC, Young IS, et al. A Posterioriderived dietary patterns and retinal vessel caliber in an elderly population. Invest Ophthalmol Vis Sci. 2013;54(2):1337-44.

26. Rodrigues PRM, Pereira RA, Cunha DB, Sichieri R, Ferreira MG, Vilela AAF, et al. Fatores associados a padrões alimentares em adolescentes: um estudo de base escolar em Cuiabá, Mato Grosso. Rev Bras Epidemiol. 2012;15(3):662-74.

27. Ferreira PM, Papini SJ, Corrente JE. Diversity of eating patterns in older adults: A new scenario? Rev Nutr. 2014;27(1):67-79. http://doi. org/10.1590/1415-52732014000100007 
28. Borges CA, Rinaldi AE, Conde WL, Mainardi GM, Behar D, Slater B, et al. Padrões alimentares estimados por técnicas multivariadas: uma revisão da literatura sobre os procedimentos adotados nas etapas analíticas. Rev Bras Epidemiol. 2015;18(4):837-57.

29. Neumann AIP, Martins IS, Marcopito LF, Araujo EAC. Padrões alimentares associados a fatores de risco para doenças cardiovasculares entre residentes de um município brasileiro. Rev Panam Salud Pública. 2007;22(5):329-39.

30. Cunha DB, Almeida RMVR, Sichieri R, Pereira RA. Association of dietary patterns with $\mathrm{BMl}$ and waist circumference in a low-income neighbourhood in Brazil. Br J Nutr. 2010;104(6):908-13.

31. Rossi M, Negri E, Bosetti C, Dal Maso L, Talamini $R$, Giacosa $A$, et al. Mediterranean diet in relation to body mass index and waist-to-hip ratio. Public Health Nutr. 2007;11(2):214-7.

32. Olinto MTA, Gigante DP, Horta B, Silveira V, Oliveira I, Willett W. Major dietary patterns and cardiovascular risk factors among young Brazilian adults. Eur J Nutr. 2012;51(3):281-91.
33. Arruda SPM, Silva AAM, Kac G, Vilela AA, Goldani $\mathrm{M}$, Bettiol $\mathrm{H}$, et al. Dietary patterns are associated with excess weight and abdominal obesity in a cohort of young Brazilian adults. Eur J Nutr. 2016;55(6):2081-91.

34. Xu X, Byles J, Shi Z, McElduff P, Hall J. Dietary pattern transitions, and the associations with BMI, waist circumference, weight and hypertension in a 7-year follow-up among the older Chinese population: A longitudinal study. BMC Public Health. 2016;16:743.

35. Jonge EAL, Rivadeneira F, Erler NS, Hofman A, Uitterlinden $A G$, Franco $O H$, et al. Dietary Patterns in an elderly population and their relation with bone mineral density: The Rotterdam study. Eur J Nutr. 2016;105(1):203-11.

36. Ferreira SRG. Alimentação, nutrição e saúde: avanços e conflitos da modernidade. Ciênc Cult. 2010;62(4):31-3.

Received: July 10, 2017

Final version: October 17, 2017

Approved: November 13, 2017 